\title{
Geweld in 'n evangelie van liefde: Die Evangelie van Johannes se perspektief op geweld teen Jesus en sy dissipels
}

\author{
Jan van der Watt en Kobus Kok \\ Departement Nuwe-Testamentiese Wetenskap \\ Universiteit van Pretoria
}

\begin{abstract}
Violence in a gospel of love: The perspective of the Gospel of John on violence against Jesus and his disciples

This article is the first of two articles in which violence in the Gospel of John is discussed. In these articles strong techniques of vilification in the Gospel are pointed out, according to which the status of the opposing group is radically discredited by the Jews on the one hand, and the followers of Jesus on the other hand. In the first article violence and vilification by the Jews, or disciples of Moses against the followers and disciples of Jesus are investigated. It is argued that the central issue of the conflict revolves around the question: Where is God's presence to be found? Among the Jews or among the followers of Jesus? The conflict and violence in John could be understood against the backdrop of this important question.
\end{abstract}

\section{INLEIDING}

Die volgende statistieke toon hoe Suid-Afrika in 'n knelgreep van geweld vasgevang is (De Beer 2007:6). ${ }^{1}$ Sedert 2001 is daar reeds 130,000 mense in die land vermoor (vgl 9/11 se 3,000-4,000). Volgens 'n bepaalde indeks wat die mate van onvrede/vrede in lande meet, het Suid-Afrika die 99ste plek uit 120 lande ingeneem wat onvrede betref - dit is 'n posisie wat Suid-Afrika tussen lande plaas wat deur oorlog geteister word. Die Mo Ibrahim-indeks beskryf Suid-Afrika op twee na as die onveiligste staat (uit die 48 state wat

\footnotetext{
${ }^{1}$ Vergelyk ook die onlangse golf van xenofobiese geweld wat op sommige plekke in SuidAfrika uitgebreek het.
} 
gemeet is) suid van die Sahara. Hoe akkuraat hierdie metings ook al is, dit dui op die ernstige probleem waarmee Suid-Afrikaners gekonfronteer word as dit by die realiteit van geweld kom. Van die jongste statistiek wil dit dan ook hê dat aanvalle in gewelddadigheidsgraad aan die toeneem is. De Beer (2007:6) praat selfs van 'n staat van beleg waarin die vryheid van individue ernstig aan bande gelê word.

Geweld $^{2}$ kan op verskillende wyses gedefinieer word en op verskeie maniere manifesteer (De Beer 2007:5). Dit kan beskryf word bloot as die fisieke benadeling van 'n persoon deur die misbruik van mag of krag op 'n vlak bo die redelike, wat gewoonlik meetbaar is, tot by die moeiliker of glad nie meetbare geestelike of sielkundige geweld waarmee 'n persoon benadeel of seergemaak kan word. Die keuse van 'n spesifieke definisie hang gewoonlik met die gangbare antropologie binne 'n gemeenskap saam. 'n Breër definisie, wat nie alleen fisieke geweld insluit nie, maar ook sosiale en verbale geweld, gaan hier gebruik word.

Kan ons iets oor geweld leer uit die Evangelie en Briewe van Johannes wat bekend is as die boeke van liefde? Hays meen dat daar glad nie oor geweld in hierdie Evangelie besin word nie. Hy is korrek as hy opmerk dat "The entire conflict with Judaïsm is focused on christological issues ..." (Hays 1996:139). Ridderbos (1997:452) merk ook tereg op dat die liefde die belangrikste onderliggende motief vir die sending van die Seun in Johannes se denke is (vgl Joh $3: 16 ; 15: 13 ; 17: 26)$. Die liefde van die Seun word volgens hom ook duidelik in Johannes 13 as Jesus die dissipels se voete was - liefde wat hy tot aan die einde met sy dood konkreet sou uitleef. Ons insiens word dit in Jesus se priesterlike gebed tot sy Vader in 17:26 duidelik dat die openbaring van wie die Vader is, ten nouste saamhang met die beeld van liefde. Dit is met ander woorde in die konteks van die liefde dat die Vader geopenbaar word en die rykdom van die evangelie uitkristalliseer. Jesus beskou die liefde as 'n gebod (Joh 13:34-35; kyk ook Kümmel 1973:303). Ja, so lief het God die wêreld gehad, dat Hy sy unieke Seun gegee het (Joh 3:16), want Hy is immers liefde (1 Joh 4:8) en sy kinders moet juis aan hulle liefde uitgeken kan word (Joh 13:34-35; Schackenburg 1990:1.399; Morris 1995:203; Carson 1991:205; Brown 1970:611). Hays (1996:143) is korrek as

\footnotetext{
${ }^{2}$ Hier gaan daar nie veel oor verskillende geweldsteorieë gesê word nie, hoewel die toepasbaarheid van teorieë soos die van Girard $(1977,1986)$ of Desjardins (1997) nie betwyfel word nie. Die artikel van Van Henten in hierdie bundel gee 'n oorsig daarvan. Persoonlik kom van die teorieë vir my abstrak voor en ek wonder of dit die verstaan van die Johannese teks werklik sal bevorder. Daar is ook vrae oor die werklike toepasbaarheid oor van die teorieë op 'n antieke teks soos dié van Johannes. Ons sou egter hoofsaaklik in die artikel by 'n eksegeties-teologiese analise van die teks wou bly, sonder om te vinnig toepassings op die hede te maak, veral nie op die basis van moderne geweldsteorieë nie.
} 
hy opmerk dat: "The bond between Jesus and the believers is determinative for the community's ethical norms."

By nadere ondersoek blyk dit tog dat geweld op verskillende vlakke sentraal in die Evangelie van liefde staan. Die Evangelie van liefde is inderdaad ook ' $n$ Evangelie van geweld. Die Evangelie is ryklik besaai met geweldstaal en geweldsmetafore, soos kruisiging (Joh 19:6, 10, 15), aan 'n paal ophang (Joh 3:14), 'n mens wat soos 'n saad sterf (Joh 12:24), skape en selfs ' $n$ herder wat doodgemaak word (10:10), mense wat metafories gesproke soos takke van 'n druiwestok afgesny word (Joh 15:2), swaarde wat getrek word (Joh 18:10) en mense wat geslaan of selfs vernietig word, onderlinge uitwerping van mekaar (Joh 9:34; 12:30; 15:6), oordeel (Joh 8:15) wat gevel word en kwetsende beledigings (Joh 10:20) wat rondgestrooi word, ensovoorts. Die verhaal van die Evangelie is uiteindelik ook ' $n$ verhaal van geweld (kyk ook Ridderbos 1997:315; Schnackenburg 1990:2.213; Martyn 2003).

Twee kort algemene opmerkings moet eers gemaak word: a) Die verhaal van Jesus loop op die kruis uit, wat dit inherent 'n geweldsverhaal maak. ${ }^{3}$ In die artikel gaan daar nie spesifiek op die sentrale aspek van geweld gekonsentreer word nie, aangesien dit bekend is. b) Die uiteensetting van die omvangryke materiaal oor geweld in hierdie Evangelie gaan in twee aflewerings aangebied word.

\section{2. 'N SITUASIE VAN KONFLIK}

\subsection{Die Johannese groep as 'n minderheid in 'n intimiderende gemeenskap}

Die Johannese groep het hulleself in ' $n$ ingewikkelde situasie bevind (Van der Watt 2007:127). Te midde van die skynbaar inner-Joodse konflik het hulle al duidelik as 'n afsonderlike groep met 'n eie identiteit gefunksioneer, hetsy as skool, sektariese groep of gemeenskap (Motyer 1997:115-116; Brown 1977; Culpepper 1975; Cullmann 1975). As volslae minderheid in die gemeenskap het hulle onder sterk druk van die groter en kragtiger sosiale groeperinge rondom hulle geleef, veral van die gemeenskap wat skynbaar naaste aan

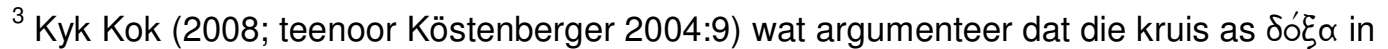
Johannes nie die realiteit van die geweldshandelinge, gebrokenheid, verwerping en

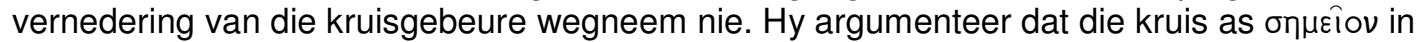
Johannes (vgl Joh 2:18-22) gerepresenteer word as $\delta o ́ \xi \alpha$ in die lig van die opstanding, soos duidelik blyk uit die onlosmaaklike verband tussen die kruis en die opstanding vir Johannes (vgl Joh 10:17-18). Die vernedering, verwerping en geweld is met ander woorde steeds 'n wesenlike realiteit in die Jesus-narratief, maar word retrospektief deur die lens van die

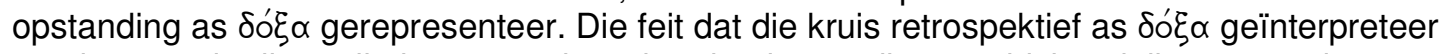
word neem nie die realiteit en negatiewe betekenis van die geweldshandelinge weg nie.
} 


\section{Geweld in 'n evangelie van liefde}

hulle gestaan en waaruit hulle gegroei het, naamlik die "Jode" of "dissipels van Moses" soos Johannes hulle noem (Joh 9:28; 15:18-16:4). Dit het hulle sosiaal voor duidelike eise gestel. Die Johannesgroep moes dus vanuit 'n posisie van relatiewe magteloosheid hulleself binne sosiale groepe handhaaf wat die mag in die hande gehad en dit ook negatief teen hulle gebruik het (Joh 9:34), selfs in die vorm van konkrete, fisieke geweld (Joh 16:2) (Barrett 1978:485; Bultmann 1971:556; Brown 1970:691; Moloney 1998:434). Dit het gevra dat hulle in hulle aanpak van die sosiale werklikheid rondom hulle sosiale gedrag volg wat tot hulle eie behoud lei (dit veronderstel 'n sagter meer akkommoderende sy), maar dat hulle nie daardeur hulle eie identiteit opoffer of verloor nie (wat 'n meer rigiede benadering vereis). Hulle was dus nie in 'n posisie of in staat om met soortgelyke fisieke geweld teenoor die sterker opponente te antwoord nie. As dit oor geweld gaan is die vraag dus, hoe handhaaf gelowiges hulleself as minderheidsgroep in 'n gemeenskap wat konkreet vyandig teenoor hulle optree en nie andersom nie.

\section{2 'n Scenario vir die geweldsituasie van die Johannese groep}

De Beer (2007:11) beklemtoon die bepalende rol van omstandighede in die evaluering van geweld. Die situasie waarin die Johannese groep hulleself bevind en waarbinne die teks gegroei en gefunksioneer het, is kompleks om te konstrueer. Daar word verskillende teorieë aangebied oor die groei van die groep (wat uit verskillende dele van die Evangelie weerspieël word) waarop nie hier ingegaan kan word nie. ${ }^{4}$ Die uitgangspunt hier gaan die teks in sy huidige vorm wees (sinkronies), met die veronderstelling dat daar wel groepsgebeure in die Jesusnarratief weerspieël word (vgl die sogenaamde "tweevlak drama;" Martyn 2003; Reinhartz 2001).

Daar is feitlik algemene konsensus dat die situasie wat in die Evangelie weerspieël word, van 'n sterk konflik tussen die "dissipels van Moses"5 (vgl

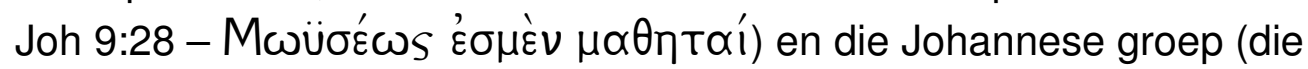
"dissipels van Jesus") spreek. Die essensie van die konflik het op 'n sentrale vraag gefokus: Waar (bv by die dissipels van Moses of by Jesus se volgelinge) en hoe (bv in die wet/tempel of in Jesus) is die ware God te vinde?

\footnotetext{
${ }^{4}$ Materiaal hieroor is in feitlik elke inleiding en kommentaar beskikbaar. Kyk byvoorbeeld Brown; Van der Watt (2007:112).

${ }^{5}$ Die identiteit van die Jode is 'n onderwerp wat deesdae wyd bespreek word - kyk byvoorbeeld Coloe (2001:1-4), Reinhartz (2001:213-227) en Bieringer (2001), om maar 'n paar van die mees onlangse publikasies te noem. Die "Jode" in die Evangelie moet nie met die moderne Jode verwar word nie en ook nie met alle Jode in die antieke tyd nie. Jesus en sy dissipels was immers ook Jode (De Jonge 2001:121-140; Lieu 2001:110-113). De Boer (2001:141-157) argumenteer dat die "Jode" in die Evangelie 'n sosio-religieuse kategorie van persone is wat hulleself as die "dissipels van Moses" identifiseer (Joh 9:28; Ashton 1994:4449). Daar sal nie hier 'n poging gemaak word om die "Jode" te identifiseer nie. Hulle sal beskryf word aan die hand van inligting wat in die Evangelie self na vore tree - dit is immers binne die narratief 'n fiktiewe groep wat bepaalde kwaliteite vertoon.
} 
Dit is dus die vraag na die teenwoordigheid van die ware God. Die beslissende vraag in Johannes sentreer dus rondom die vraag na die ware sentrum (Kok 2008:327; Van der Watt 2005:102): Waar, en by wie is God te vinde? Die vraag word natuurlik radikaal anders deur die dissipels van Moses as deur die dissipels van Jesus beantwoord en hul antwoord word gebaseer op die verskil in hulle interpretasie van die persoon en identiteit van Jesus. Beide groepe het beweer dat God eksklusief aan hulle kant is en dat hulle godsdiens outentiek is. Verwysings na die volgende gedeeltes in die Evangelie van Johannes laat ons iets van die konflik verstaan. Die fokus van die Evangelie, soos dit in Johannes 20:30-31 beskryf word, sentreer rondom twee sake:

- Mense moet in Jesus Christus as die Seun van God glo.

- As hulle glo, sal hulle (deur Jesus) die ewige lewe kry. Hulle sal met ander woorde in 'n ewige verhouding met die ware God kom.

Dit is duidelik dat die Evangelie van Johannes performatief rondom die skep van 'n unieke verhouding met God deur Christus funksioneer en gestruktureer is (Joh 5:18-19; 10:30; kyk Carson 1991:394; Ridderbos 1997:371; Stibbe 1993:118; Van der Watt 2003). Christus is die unieke Seun wat die egte verhouding met God moontlik kom maak. Dit word elders in die Evangelie bevestig in uitsprake soos dat Jesus die Een is wat die Vader moet kom

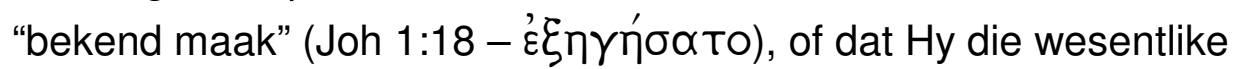

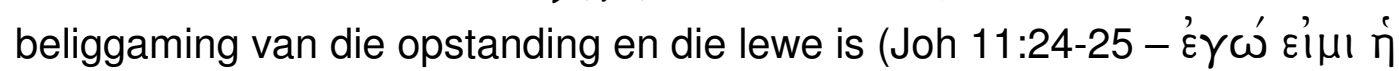

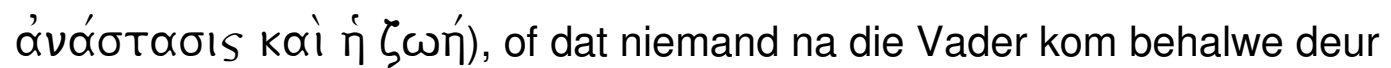

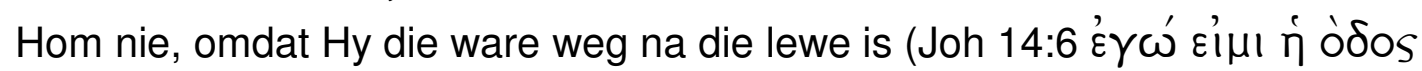

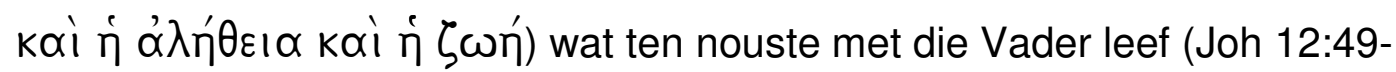
$50)$.

Juis hierdie moontlikheid dat Jesus die Een is wat die unieke verhouding met God moontlik maak, word deur die Jode sterk betwyfel tot op die punt waar hulle bereid is om tot ekstreme geweld, ja, tot moord oor te gaan. Hulle hoofkritiek teen Jesus word byvoorbeeld in Johannes 5:16-18 verwoord as basis vir hulle besluit om Jesus dood te maak:

- Hy maak iemand op die Sabbat gesond, wat beteken dat Jesus nie volgens die gangbare Joodse interpretasie van die Sabbat optree nie

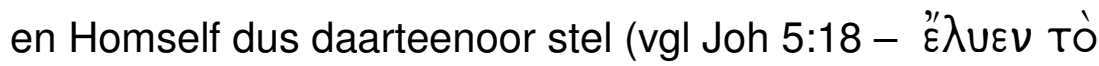
$\sigma \alpha \dot{\beta} \beta \alpha$ Tov). Hy is 'n wetsoortreder. 


\section{Geweld in 'n evangelie van liefde}

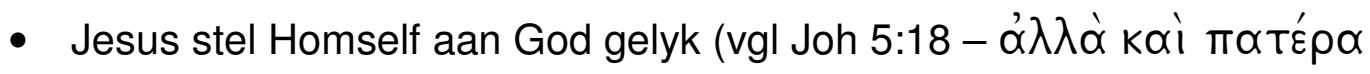

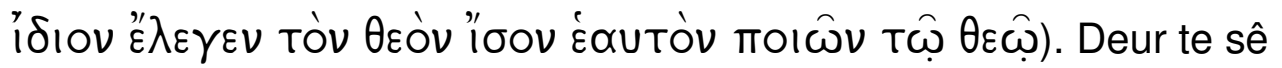
dat Hy soos die Vader op die Sabbat mag werk het Hy Homself aan die Goddelike kant geplaas. Dit is as laster deur die Jode ervaar, soos wat later uit die Evangelie blyk. Daar word dit selfs die hoofargument waarom Jesus gekruisig moes word (Joh 10:31-38; 19:7). Die opponente aanvaar Hom en sy boodskap rakende sy eie goddelike identiteit dus nie (1:9-11; vgl Haenchen 1984a:117).

Die dissipels van Moses ervaar met ander woorde Jesus se optrede en uitsprake duidelik as laster en gevolglik as aantasting van die eer van God. (Kyk ook Joh 5:23). Die essensie van die probleem is duidelik: vir die Jode staan Jesus nie aan die kant van God nie, maar is 'n sondaar (Joh 9:24) wat met die duiwel deurmekaar is (Joh 7:20; 8:48, 52; 10:20-21). Dit is meer as duidelik uit sy optrede gedurende die Sabbat wat van minagting teenoor die wet spreek, soos party van die Fariseërs reguit sê (Joh 9:16 - oủK हैoTıV

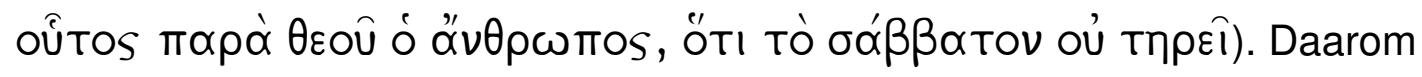
verdien Jesus in hulle oë niks anders as die dood nie (kyk ook Joh 12:9-11; vgl Schnackenburg 1990:2.370). Die implikasie hiervan en dus ook die wortel van die probleem, word so duidelik:

- Die twee groepe maak beide aanspraak op dieselfde God, maar

- beide groepe eien die teenwoordigheid en werking van God net vir hulleself toe en ontken die teenwoordigheid van God in die ander groep.

Hiermee word die prominente dualistiese wêreldbeeld van Johannes geillustreer (Van der Watt 2000). Lig staan teenoor duisternis soos lewe teenoor dood en die Seun teenoor die duiwel staan (vgl Joh 8:48). In 'n dualistiese wêreldbeeld is konflik altyd teenwoordig - jy beweeg óf in die sfeer van waarheid óf in die sfeer van leuens (Joh 8:44; kyk Witherington 1995:178). Die intensiteit van die debat lê daarin dat die redding inderdaad van die Jode kom (Joh 4:22; Ashton 1994:45). Dit is waar die ware God te vinde is en aanbid kan word (Joh 4:19-24). Beide die opponerende groepe is inderdaad Jode, soos blyk uit die argument in Johannes 8 oor hulle vader Abraham of in Johannes 5 en 6 oor Moses. Beide groepe maak dus daarop aanspraak dat hulle die enigste God aanbid en dus die sleutel en kopiereg op daardie aanbidding hou. Laasgenoemde lei dan tot die wedersydse uitsluiting en vilifikasie van mekaar. 
Dit bring ons by 'n volgende kernprobleem: Die Joodse godsdiens is 'n ou en kulties goed ontwikkelde godsdiens. Die Jode het konkrete en sigbare bewyse gehad van God se bemoeienis met hulle, byvoorbeeld die verbond, die Wet, die profete, die Tempel, die reinheidsgebruike, offers, die hou van heilige dae, soos die Sabbat en ander feesdae, ensovoorts. Dit is dus moeilik te betwyfel dat God by en tussen hulle aan die werk is. Om te beweer dat God nie by hulle is nie, sou vergesog klink. Tog beweer die dissipels van Jesus dit.

Die vertrekpunt van Jesus se dissipels is die Woord wat gekom het om God te kom bekend maak (Joh 1:18), ${ }^{6}$ met ander woorde, openbaringsteologie. God het 'n nuwe pad gekies en 'n nuwe familie kom bymekaar maak onder leiding van die Messias, God se Seun wat God gestuur het. Die profesieë van die Gees wat kom en alles sal kom nuut maak of restoureer (Joh 3 ) is besig om onder die dissipels van Jesus in vervulling te gaan (Joh 7:39; Bennema 2002). Essensieel druk Jesus dit kernagtig uit as Hy sê (Joh

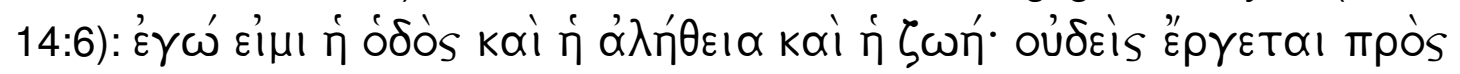

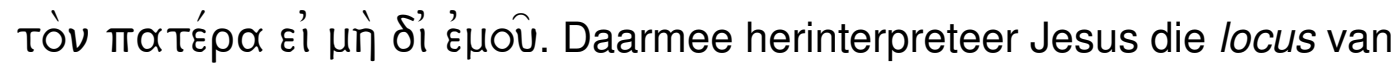
God en aanbidding van God (kyk Carson 1991:491) wat nie meer in Jerusalem nie, maar in die Gees en waarheid wat in die openbaring van Jesus te vinde is (Joh 4:21-24).

Die woorde van Jesus is paradigmaties vir wat tussen die Johannesgroep en die Joodse godsdiens gebeur het. Die Joodse merktekens van die teenwoordigheid van God by hulle, soos die tempel, Wet, Sabbat, ensovoorts is alles vergeestelik en binne die eskatologiese werklikheid van Jesus se teenwoordigheid opgeneem. Jesus is nou funksioneel die tempel; Hy reinig, die Wet en die profete getuig van Hom; Hy is die lam en die lig, en so kan voortgegaan word. Die konkrete bewyse van God tussen die dissipels van Moses word dus funksioneel van waarde ontneem en die funksionaliteit word op Jesus oorgeplaas. Wat in die ou tyd van kultiese dinge soos die tempel, die Wet, Sabbat, onder die Jode waar was, is nou alleen in Jesus waar. Dus: God, in God se volle werking, is alleen by Jesus te vinde.

Johannes se antwoord is duidelik: God kan alleen deur geloof in Jesus ontmoet word, en die Gees getuig daarvan. Dinge is nie meer dieselfde nie, maar het verander, want Jesus, die Messias, die Seun van God is hier (Joh 3:16; 4:25-26) om die wil van die Vader bekend te maak (Joh 1:18). Jesus staan dus in die lyn van die Skeppergod (Joh 1:3), die God van Abraham, Moses en die profete. Hy bring nie 'n nuwe godsdiens en verteenwoordig ook nie 'n nuwe god nie, maar is die voortsetting van die ou godsdiens wat met die

\footnotetext{
${ }^{6}$ Köstenberger (2004:48-49) beklemtoon die intieme verhouding tussen die Vader en die Seun in Johannes en argumenteer dat dit Jesus in 'n unieke posisie plaas om die Vader te openbaar aan die wêreld, maar bou nie die aard van die openbaringskennis uit nie.
} 


\section{Geweld in 'n evangelie van liefde}

God van die skepping begin het. En waar laat dit die Jode? Met leë kultiese artefakte en sonder God. Die bewering het natuurlik die Joodse opponente die harnas ingejaag.

Die konflik oor wie en waar God is in verhouding tot Jesus is duidelik uit die debatte met sy opponente soos wat dit byvoorbeeld duidelik blyk in Johannes 8:14-59 of 10:31-39. Hoewel beide partye dieselfde religieuse en kulturele agtergrond deel (voorgeslagte, Skrif, profete, tempel, ens), beide streng gesproke met die naam "Jode" verbind kan word en duidelik dieselfde God in gedagte het, verskil hulle opinies oor God radikaal, veral in verhouding tot Jesus en sy optrede tot op die breekpunt van ekstreme opposisie en selfs veragting. Jesus se volgelinge hou vol dat as iemand nie die beeld en realiteit van God soos dit in Jesus na vore tree aanvaar nie, is hulle sonder God, al beweer hulle hulle aanbid dieselfde God (Kyk Joh 14:7; vgl Schnackenburg 1990:3.64). Die Joodse opponente sien Hom as van die duiwel besete (Joh 7:20; 10:20). Is Jesus "my Here en my God" (Joh 20:28) of 'n "Samaritaan en duiwelbesetene" (Joh 8:48)? Dit definieer dus die essensie van die konflik en verskaf ook die rede waarom Christologie en soteriologie nie geskei kan word nie.

So 'n "kaping" van die Joodse godsdiens kan natuurlik nie sonder konflik gebeur nie. Dit is juis waarvan die Johannesevangelie ons vertel. Juis omdat die konflik oor die "besit van God" handel, kan die Jode uitermate geweld gebruik en die Christene doodmaak en dan nog dink dit is wat die beoefening van hulle godsdiens van hulle vereis (Joh 16:2).

Die konflik word deur 'n magswanbalans gekenmerk. Die Joodse groepe word as persone met aardse, institusionele en politieke mag geïdentifiseer met wye invloed oor die Joodse gemeenskap. Dit blyk byvoorbeeld wanneer hulle sê dat mense wat van Jesus hoor, dit moet aanmeld en wanneer Johannes 9 aandui hoe bang die gewone mense vir die leierskap was. Hulle invloed strek ook selfs tot binne in die Romeinse regeringsetel. Dit blyk daaruit dat hulle Pilatus dwing om teen sy wil Jesus te laat kruisig (Joh 19). Hulle het ook 'n "polisiemag" tot hulle beskikking gehad (Joh 18:3). Niks hiervan is van die Johannese groep waar nie. Hulle het nie werklik toegang gehad tot so iets nie, soos blyk uit die ironiese verhaal van Petrus wat sy swaard getrek het om teen die oormag te veg en toe deur Jesus berispe is (Joh 18:10). Dit alleen is 'n belangrike punt in die behandeling van geweld in die Johannesevangelie - as jy nie toegang tot georganiseerde mag het nie, dan sal jy waarskynlik ook nie besin oor wat jy sou doen as jy dit gehad het nie. 


\section{GEWELDSLYNE VAN DIE DISSIPELS VAN MOSES}

Die begin (proloog) van die Evangelie van liefde is reeds in die skadu van duisternis (Joh 1:5; 3:19; 8:12; 12:35; 12:46) en verwerping gehul (Joh 1:511). Culpepper $(1981,1983)$ argumenteer dat die plot van die Evangelie al in Johannes 1:9-13 gegee word: Jesus kom na sy eie mense toe en hulle verwerp Hom. Hulle wil Hom nie hê nie. Tog is daar 'n ligpunt, naamlik dat daar sommiges is wat Hom aanvaar. Sosio-kultureel was gasvryheid 'n basiese waarde in die antieke wêreld (Joubert et al 1996). Om "jou eie" dus nie te aanvaar nie, veral as in ag geneem word dat die persoon sulke titels dra soos "koning van die Jode", "Messias", "Seun van God,", is 'n kru vorm van verwerping. Hoe gewelddadig hierdie verwerping werklik is, blyk uit die aksielyne wat in die res van die Evangelie volg. Daaraan gaan nou kortliks aandag gegee word. Dit gaan aan die hand van twee hooftemas ontwikkel word, naamlik, die fisieke voorneme om Jesus gewelddadig uit die weg te ruim en die vilifikasie van die persoon van Jesus.

\subsection{Gewelddadige besluite en aksies deur die opponerende Jode}

Die negatiewe en aggressiewe aksielyn van die opponerende Jode begin reeds in die proloog met die beskrywing van die plot, soos voorheen gemeld is. Jesus word nie deur sy eie mense aanvaar nie (Joh 1:9-11). Die volle impak van die plotbeskrywing word weldra duidelik. Die eerste tekens kry ons in Johannes 2:23-25 waar Jesus sê dat Hy Hom nie aan die Joodse massa in Jerusalem kan toevertrou nie, 'n stelling wat volgens Thyen (2006) in Johannes 4:43-46 weerklank vind as daar oor Jesus gesê word dat 'n profeet nie in sy eie land geëer word nie. Hy word in die setel van die destydse Jodedom (Hy was self 'n Jood) verwerp.

Die aksielyn word gewelddadig in Johannes 5:18 - waar die Jode besluit om Jesus dood te maak op grond van die twee aanklagtes wat hierbo

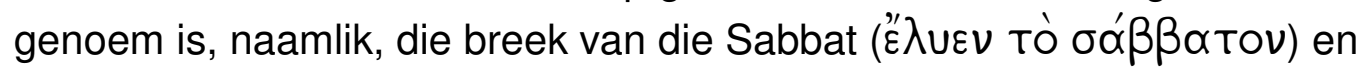
laster (vgl 19:7), beide sterk religieus gekleurde aanklagte. Hierdie aksielyn van die doodmaak van Jesus word deur die res van die Evangelie opgeneem en bespreek totdat alles in die kruisdood van Jesus kulmineer (Joh 19:15-29). In Johannes 7:1, 25 word die feit dat die Jode Jesus wou doodmaak as 'n algemeen bekende feit onder die mense gestel en in Johannes 11:8, 16 by monde van die dissipels geresoneer. Jesus word dan ook uiteindelik op die brutaalste wyse tereg gestel, naamlik gekruisig. In die antieke tyd was kruisiging spesifiek vir ekstreme oortredings bedoel wat die gemeenskap in gevaar gestel het, byvoorbeeld vir verraaiers, wegloper slawe, vyande wat verslaan is, of persone wat die koning of regeerder bedreig (Van der Watt \& Joubert 1996). 
Omdat die doel van kruisiging was om as afskrikmiddel te dien, was dit sosiaal vernederend en onterend. Die aksielyn van geweld teen Jesus eindig op 'n uiters brutale en vernederende wyse. ${ }^{7}$

Die uitsprake moet in perspektief geplaas word. Die intensie is dat die dominante en leidende groep in die gemeenskap 'n probleem in die gemeenskap wil uitskakel. Dit word as geregverdig gesien, met ander woorde, in terme van teregstelling van 'n skuldige persoon. Dit sou as geregverdigde geweld gesien kon word. Wanneer 'n mens tussen die lyne lees, lyk dit nie of die outeur van Johannes beginsel-probleme met so 'n geregverdigde teregstelling het nie. Tog, vanuit die outeursperspektief is dit wat met Jesus gebeur nie geregverdigde teregstelling nie, maar moord (Joh 8:44), want Jesus is onskuldig. Pilatus sê dit ook oor en oor in sy verhoor - Johannes 1819. Om so 'n persoon wetend onskuldig tereg te stel sou neerkom op oordadige en ongeregverdigde geweld, oftewel moord. Dieselfde tipe geweldsdaad se morele waarde weeg dus anders na gelang die perspektief op die situasie verander. Die werklike vraag is uiteindelik wie die regter is wat in beheer is van die norme. Vir Johannes word die perspektief gemeet aan die waarheid van sy Vader, en Jesus is natuurlik die waarheid (Joh 14:6; kyk ook 18:37-38). Daarom is die reg om te oordeel aan Hom gegee (Joh 5:22). Dit maak die oordeel van sy opponente per se verkeerd.

Die aksielyn van moord (kruisiging) is nie al aksielyn van betekenis nie. ${ }^{8}$ Verskillende aksielyne wat verskillende tipes geweld verteenwoordig, word met die aksielyn van moord vervleg tot 'n koherente geweldsprofiel. Dit kan kortliks aandag ontvang.

- $\quad$ Die gemeenskap word bewustelik teen Jesus (en sy volgelinge) gemobiliseer deur middel van intimidasie deur die owerheid. Die intimidasie maak die blinde man se ouers (Joh 9) asook van die ander Jode selfs te bang ('£фoßoûvTo) vir die Joodse leierskap om iets te doen wat positief teenoor Jesus mag lyk (Joh 7:13; 9:22). Hulle word byvoorbeeld opdrag gegee om die leierskap te laat weet as hulle Jesus iewers opmerk sodat Hy gevange geneem kan word (Joh 11:57). Die kulminasie van die gemeenskapsmobilisering is uiteindelik die

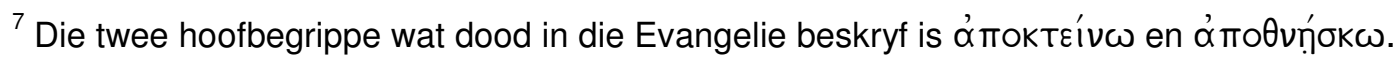
Laasgenoemde term word gebruik om die aksie van sterwe of doodgaan ( $\mathrm{d}$ w s iemand of iets hou op lewe) aan te dui (lemand sterf, soos voorouers, 'n kind of Lasarus: 4:47, 49; 6:49; 8:21, 24, 53; 11:14, 16, 21,32, 37; 11:50, 51; 12:33; 18:14, 32; 19:7; $21: 23$. Ewige sterwe:

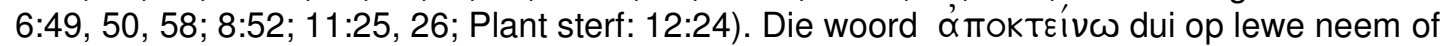
doodmaak (dws iemand anders se lewe wegneem of beëindig (lemand [wil] doodmaak: 5:18; 7:1, 20, 25; 8:37, 40; 11:53; 12:10; 16:2; Selfmoord: 8:22).

${ }^{8}$ Aangesien die gebeure rondom die kruis bekend is, word daar nie verder hierop ingegaan nie.
} 
uitsluiting uit die sosiale kringe van die Jode, oftewel, die uitbanning van die volgelinge van Jesus uit die sinagoge (vgl Joh 9:22 ámoбuvó $\gamma \omega \gamma$ ○s; kyk ook 12:42). Dit was 'n ekstreme en gewelddadige aksie in die antieke tyd. Binne die Johannese konteks, waar die twee-drama struktuur domineer, weerspieël hierdie opmerking waarskynlik die ervaring van die latere Johannese groep, wat met die verhaal van Jesus vervleg is.

- Hierdie gemeenskapsmobilisasie hang nou saam met die proses van arrestasie van Jesus. Daar word voortdurend melding gemaak van die pogings om Jesus te arresteer (Joh 7:30; 8:20, 32, 44; 10:39; 11:57) en selfs om hom (onwettig?) te probeer stenig (Joh 8:59 en 10:31-33 in die lig van 18:31). Die verhaal van Jesus ontvou binne hierdie intimiderende raamwerk van konflik en geweld.

- Die opponente word ook geskets as mense met negatiewe gesindhede wat met die energie van haat funksioneer ( $\mathrm{vgl}$ Joh 3:20; 7:7; 15:18-19, 23-24; 17:14). In Johannes 15:18-25 word die onredelike en ongegronde haat van die opponente van Jesus met vervolging en uiteindelik die dood verbind (Joh 16:2). Dit is nie net haat teenoor Jesus nie, maar primêr teenoor God. By wyse van 'n beeld word hierdie gesindheid van hulle verklaar. Hulle is soos diewe en rowers wat geen verhouding met

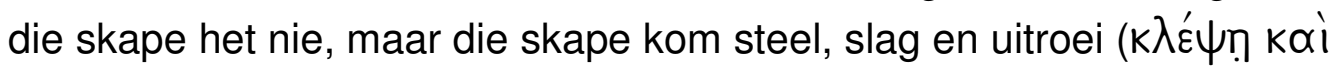

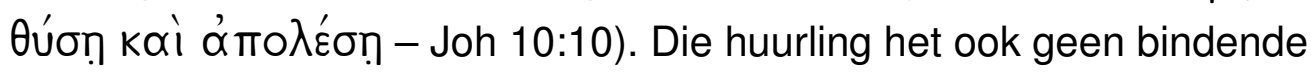
(liefdes)verhouding met die skape nie, en sal hulle dus op geen manier beskerm nie (Joh 10:11 vv). Die optrede van die Joodse opponente teenoor die volgelinge van Jesus weerspieël juis hierdie gewelddadige optrede. Sulke negatiewe aksies word na onbetrokke gesindhede teruggevoer wat in die antieke telkens met die woord "haat" verwoord word. Vanuit hierdie gesindheid van haat vloei die gewelddadige aksies wat tot moord lei (Joh 15:18 vv).

- $\quad$ Die prominente aksielyn wat maklik misgekyk kan word, is die aksielyn van vilifikasie. Vilifikasie is grootliks 'n retoriese meganisme waardeur die teks performatief werk (Du Toit 1994:403-412; Lausberg 1960:55, $61,131-138,205-206,542)$. Vilifikasie is wyd in die antieke gebruik om opponente te diskrediteer en disassosiasie met die opponente te bevorder (Du Toit 1994:404; Johnson 1989:419-441). Dit is dus ' $n$ vorm van taalgeweld. Die veronderstelling is dat die persoon wat verantwoordelik is vir die vilifikasie se gesigspunt die taalaksie kleur, wat natuurlik beteken dat die beeld van die opponente 'n konstruk van die 


\section{Geweld in 'n evangelie van liefde}

vilifiseerder is. Daar moet dus gewaak word teen "referential fallacy" waardeur die gevilifiseerde beeld met die persone in die werklike lewe gelykgestel word (Du Toit 1994:404). Hieraan moet nou verder aandag geskenk word.

\subsection{Vilifikasie van Jesus se dissipels deur die opponente}

Vilifikasie in die antieke tyd kan direk met die waardes van eer en skaamte verbind word. Dit gaan om 'n diskreditering van 'n persoon in die oë van die betrokkenes, waardeur die eer van die persoon tot skande gemaak word (Malina \& Rohrbaugh 1998:33). So word die vilifiseerder gekrediteer en sy eer verhoog. Dit het ook in die antieke 'n belangrike rol gespeel in strydgesprekke, waarin skerp uitsprake retories 'n belangrike rol gespeel het. Malina en Neyrey (1991:100) merk op: "Negative labels, in fact, are accusations of deviance. Behavior is deviant when it violates the sense of order or the set of classification which people perceive to structure their world." Negatiewe etikette het die status van die persoon self negatief verander. So 'n persoon verloor eer, wat die positiewe erkenning van iemand se waarde in die oë van ander behels het. Malina en Neyrey (1991:25) skryf in die verband: "Honor is the positive value of a person in his or her own eyes plus the positive appreciation of that person in the eyes of his or her social group. In this perspective honor is a claim to positive worth along with the social acknowledgment of that worth by others."

In die Johannesevangelie word die opponente van Jesus geskets as mense wat Jesus wil vilifiseer en negatiewe etikette op hom wil plaas. Hier volg enkele voorbeelde ${ }^{9}$ :

\subsubsection{Die beskrywing van Jesus se herkoms en karakter by wyse van beledigende kategorieë}

- Jesus se herkoms: Die geboorte en herkoms van 'n persoon was destyds van groot belang ten einde sy identiteit vas te stel. Malina en Rohrbaugh (1998:161) wys tereg daarop dat die lokaliteit van geboorte direk gekoppel word aan karakter en dat "genealogy is the only significant matrix for (ascribed) honor and status. The ancients believed that genealogy could be deduced from one's subsequent behavior and character, and that behavior and character offer solid indication of one's genealogy". Vir die antieke mense was daar met ander woorde 'n natuurlike verband tussen afkoms, sosiale eer en status. Juis om hierdie rede doen Johannes moeite om aan te toon dat Jesus in werklikheid van God self af kom (Joh 1:1-18). Die implikasie daarvan is

\footnotetext{
${ }^{9}$ Die beskrywings van du Toit (1994) is in ag geneem by hierdie uiteensetting.
} 
dat Jesus as God se Seun eer het. Indien jy nie weet waar 'n persoon vandaan kom nie, kon dit negatief op sy persoon reflekteer aangesien die persoon se herkoms boos kon wees sonder dat die mense dit weet, of aan die ander kant kon dit op goddelike herkoms dui, soos in die geval van Melgisedek en Jesus in Hebreërs (Heb 7:3,6). Die dissipels van Moses verwys egter na die feit dat hulle nie weet waar Jesus

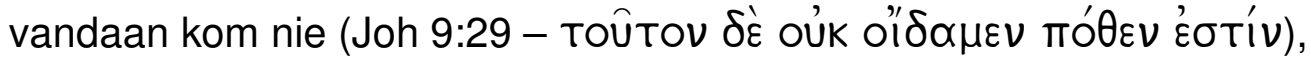
juis in die konteks waar hulle hom as sondaar beskryf (Joh 9:29, 31). In ander gevalle is dit bekend waar Jesus vandaan kom, soos Natanael wat vra of iets goeds uit Nasaret kan kom (Joh 1:46) of die Jode wat sê dat hulle sy familie ken (Joh 6:42). As Nikodemus Jesus voor die Joodse raad probeer beskerm, reageer die leiers vinnig deur vir Nikodemus daarop te wys dat Jesus uit Galilea kom en dat daar nie 'n profeet uit Galilea sal kom nie (Joh 7:51-52). Hierdie opmerkings funksioneer egter nie direk as vilifikasie nie. Die feit dat Jesus se aardse herkoms tog duidelik was onderstreep dat die verwysing in Johannes 9:29 vilifiserend funksioneer. Die agtergrond lê hier waarskynlik op die geestelike vlak, naamlik dat hulle nie wil erken dat Jesus van bo, van God af kom nie, 'n saak wat ook in Johannes 6:4243 aangespreek word. In Johannes 8:48 word Jesus "Samaritaan"

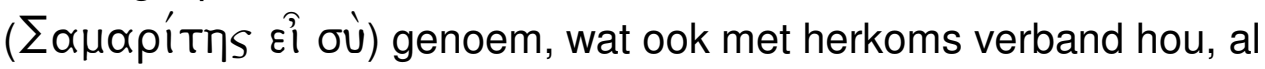
sou dit as beledigende uitdrukking bedoel gewees het. Die Jode en die Samaritane het nie oor die weg gekom nie (Barrett 1978:232). In Johannes 4:9 word die berugte vyandigheid tussen die Jode en Samaritane eksplisiet gestel. Jesus se herkoms en dus ook sy karakter word so bevraagteken en gevilifiseer.

- $\quad$ Die uitbeelding van Jesus as leuenaar: Deel van die vilifikasie van karakter is dat Jesus in Johannes 7:20 beskryf word as "demonies

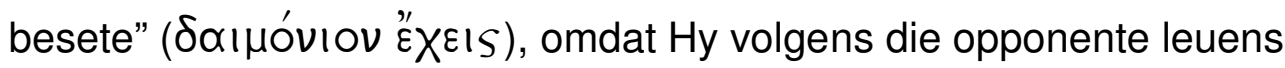
vertel, selfs as Hy oor homself praat (vgl ook Joh 8:48). Die demoniese verwyte dui daarop dat die opponente nie dink dat Jesus op redelike verantwoorde vlak normaal funksioneer nie en dat sy woorde dus nie betroubaar is nie.

- $\quad$ Die beskrywing van Jesus as opgeblase en arrogant: 'n Direkte beskuldiging van arrogansie kry ons in Johannes 8:53, waar die Jode vir Jesus vra: "Wie maak jy jouself uit om te wees?" oftewel, "Wie dink

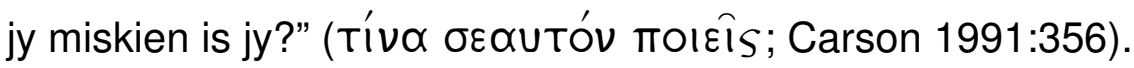
Onvermoë om jouself reg te beoordeel (gebrek aan selfkennis) was destyds in 'n baie negatiewe lig gesien. Jesus reageer direk daarna 
met 'n verwysing na waar sy eer vandaan kom - die opponente kan Hom maar vilifiseer, maar sy Vader eer Hom (vgl Joh 5:23, 41, 44; $7: 18 ; 8: 49 ; 8: 50 ; 12: 26)$.

- $\quad$ Die beskrywing van Jesus in terme van demoniese aktiwiteite: ${ }^{10}$ Jesus

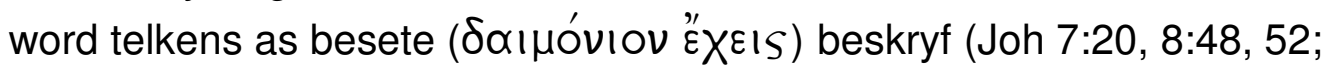
10:20 vv). Dit kom neer op ernstige verwerping en diskreditering, aangesien die opmerking binne 'n Joods-godsdienstige raam gemaak is. In Jesus se geval word Hy demonies beskryf veral vanweë sy getuienis. In Johannes 7:20 word Hy as leuenaar beskuldig, 'n aanklag wat in Johannes 8:48, 52 herhaal word as Hy oor homself praat. In Johannes 10:20-21 is Jesus se woorde weer die rede waarom die opponente Hom as 'n besetene beskryf. Die woord demoon

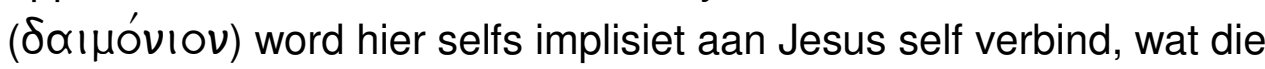
indruk laat dat die besetenheid en om demoon te wees semanties baie na aan mekaar gelê het. In Johannes 10:20 word Jesus nog sterker as

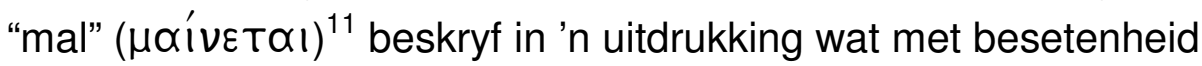
verbind is. In die antieke was dit nie aanvaarbaar om na iemand wat besete was te luister nie (Schattenmann 1986:ad loc). Dit sou dan beteken dat die opponente van die verantwoordelikheid onthef is om na Jesus te luister aangesien Hy nie by sy volle positiewe is nie. Aangesien "mal" 'n generiese term is, veral in ons hedendaagse gebruikswyse, moet daarop gelet word dat in die algemeen Griekse omgewing besetenheid met demone geassossier is met die verloor van 'n mens se redelikheid en normale verstandelike aktiwiteite gepaard gegaan het. Jy het buite die normale aanvaarbare gedragspatrone opgetree en is dus as "mal" beskryf (Bietenhart 1986:ad loc). In die konteks van Johannes 10:20, naamlik in vers 21 , word daar dan ook gevra of 'n demoon die oë van blindes kan oopmaak, wat dan juis op buitengewone optrede dui. Die gesprek gaan nou verder oor watter buitengewone omstandighede as demonies geklassifiseer kan word en

\footnotetext{
${ }^{10}$ As breë beskrywing kan gesê word dat demone in die antieke wêreld met geestelike magte verbind word wat sterker as mense is en dus tot buitengewone aksies in staat is (Bietenhart 1986:ad loc). Filo en Josefus deel hierdie opinie en stel die engele en demone gelyk, natuurlik met die verskil dat laasgenoemde vir negatiewe aktiwiteite verantwoordelik is. Demone verteenwoordig die wêreld buite God, of die goddelike sfeer. Dit is dikwels ook met towery verbind, soos wat ons ook in die Nuwe Testament sien (Gal 5:20; Op 9:20 e v, 18:23, 21:8; 22:15). Die wyse waarop demone in die algemeen Griekse wêreld beheer was, was deur toorkuns.

${ }^{11}$ Maívouoı is ' $\mathrm{n}$ tegniese term in byvoorbeeld die kultus van Dionusios wat aandui dat ' $\mathrm{n}$

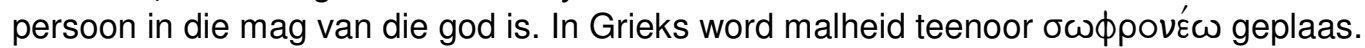
Laasgenoemde dui dan op iemand wat beheer het oor sy denke met die nodige selfbeheersing (Bietenhart 1986: ad loc; Liddle \& Scott ad loc).
} 
watter nie. Genesing behoort volgens hulle nie een daarvan te wees nie. Die konklusie konfronteer die leser natuurlik met die vraag waar hierdie buitengewone optrede van Jesus dan eintlik vandaan kom.

- $\quad$ Die beskrywing van Jesus as moreel korrup: Jesus word as leuenaar met 'n valse leer wat nie sin maak nie, beskryf (sien bo). 'n Sprekende uitspraak in die morele vilifisering van Jesus is die beskrywing van hom

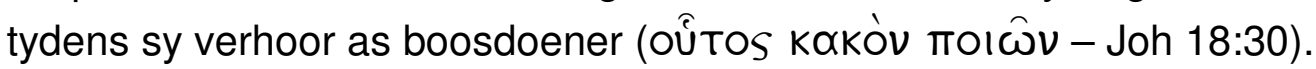
Tydens hulle gesprek met die blinde man het die Joodse leiers ook nie

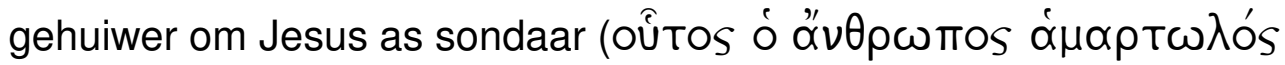
દoTIV) te beskryf nie (Joh 9:24-25). Beide die uitdrukkings dui op morele korrupsie.

\subsubsection{Insinuasie van oneerlikheid en gekonkel}

In die antieke groepsgeoriënteerde samelewing was dit van belang dat 'n persoon nie in die geheim optree nie. Dit is as gekonkel gesien. Jesus se ongelowige broers (as ongelowige verteenwoordigers uit sy nouste kring) sê

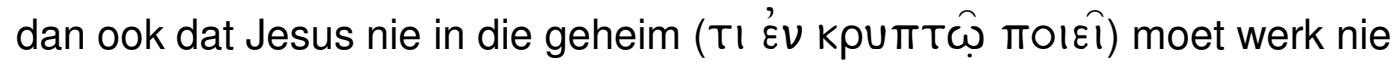
(Joh 7:4), maar openlik vir sy saak in Jerusalem moet gaan uitkom. Die uitlating kom retories sarkasties voor. In Johannes 18:20 ontken Jesus dan ook dat Hy enigiets in die geheim gedoen het as vindikasie van Homself.

\subsubsection{Die beskrywing van Jesus as iemand wat negatiewe invloede op mense rondom Hom het}

Van die mense het Jesus beskryf as iemand wat mislei (Joh 7:12; $\pi \lambda \propto \nu \hat{\alpha})$. In Johannes 11:47-48 word die invloed van Jesus polities negatief beoordeel die volk loop agter Hom aan en dit gaan daartoe lei dat die Romeine hulle gaan kom vernietig. Die beskuldiging word dan ook die sogenaamde laaste spyker in die doodskis vir die Jode.

\subsubsection{Jesus assosieer Homself met twyfelagtige karakters}

Verskeie kommentatore bring die beskuldiging dat Jesus 'n Samaritaan is (Joh 8:48) in verband met die gebeure by die Samaritane in hoofstuk 4 , 'n hoofstuk waarin die Samaritane vanuit Joodse perspektief negatief beoordeel word. Die verwysing is dus ' $n$ aanduiding van die twyfelagtige karakters waarmee Jesus meng.

Uit hierdie beskrywings is dit dus duidelik dat volgens die outeur van die Evangelie se persepsie, daar ' $n$ intensiewe aanslag van diskreditering en vilifikasie teen Jesus (en op 'n tweede vlak teen die gemeente) was. Die fokus van hierdie vilifiserende aanslag fokus op sy integriteit en persoon, met die 


\section{Geweld in 'n evangelie van liefde}

klem op Hom as oneerlike getuie en leuenaar. So word 'n vraagteken oor sy boodskap geplaas.

Die vilifisering moet binne die raam van sosiale geweld teen die agtergrond van 'n dualistiese simboliese universum gelees word. Dit lei tot desosialisering en diskreditering van die persoon. Sosiale geweld in die antieke groepsgeoriënteerde gemeenskappe was baie meer vernietigend as wat dit vandag ervaar word. Aangesien antieke persone hulle identiteit hoofsaaklik in terme van hulle groep ontdek en beskryf het, was diskreditering binne die groep feitlik gelyk aan die vernietiging van die persoon se identiteit en bestaansin binne sy gemeenskap, iets wat inderdaad 'n ernstige vorm van geweld is. Wanneer die vilifikasie in die gemeente 'n hoogtepunt bereik, word die groepslede nie alleen doodgemaak nie (Joh 16:2) maar ook uit die sinagoge (as sosiale sentrum) geban, 'n aksie van totale desosialisering en dus skande. Soos De Beer (2007:8) tereg opmerk, word verskillende tipes geweld, soos taalgeweld, terreur geweld, fisieke geweld en so meer met mekaar verweef. In hierdie geval lyk dit dus of taalgeweld aanleiding gee tot fisieke of selfs institusionele geweld (van die kant van die Joodse Raad) wat dan uiteindelik op die dood uitloop.

Daar word dus 'n duidelike netwerk gespan van negatiewe gesindhede wat tot die diskreditering van Jesus lei, vervleg met beplanning om Jesus gevange te neem en uiteindelik die aktiewe optrede deur die opponente wat tot Jesus se dood lei.

Die beskrywing van die geweld teen Jesus word natuurlik binne die tweevlak drama op die gemeente geprojekteer (en omgekeerd, bv die uitbanning uit die sinagoge). Sy volgelinge ervaar uiteindelik dieselfde as Jesus en soortgelyke optrede word dan ook teen hulle verwag. Jesus formuleer dit self in Johannes 15:18-27 so dat soos sy opponente Hom gehaat het, hulle sy volgelinge ook gaan haat. Dit wat Jesus tref, sal die dissipels ook tref, tot en met die dood (Joh 16:2). In die lig moet die dissipels van Jesus verwag om sy bestaan te voer binne die raam van konstante geweld van die kant van mense wat Jesus nie as Seun van God aanvaar nie. Daar kan selfs gevra word of geweld nie as wesentlike deel van Christelike gemeente-wees gestel word nie.

'n Laaste vraag in die verband is hoe hierdie aksielyne van geweld deur die opponente van Jesus gelegitimeer is. Die outeur van die Evangelie gee baie verklarings vanuit sy outeursperspektief waarby later stilgestaan gaan word. Tog lyk dit of die basiese legitimasie deur die opponente van

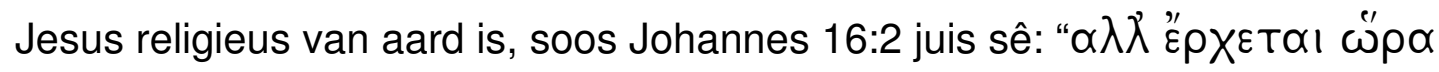

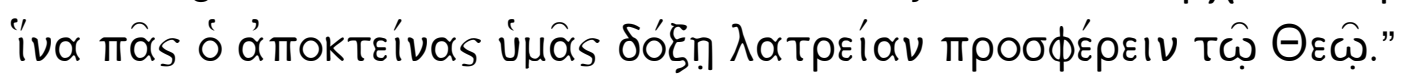
Die opponente sal dink hulle dien God deur volgelinge van Jesus dood te 
maak. Inderdaad, as hulle Jesus aankla voor Pontius Pilatus, doen hulle dit omdat hulle gedink het Hy laster (Joh 19:7 in die lig van 10:33). Dit bring ons dan by dit wat aan die begin gesê is: die basiese strydpunt waaroor die hele konflik gaan is naamlik, waar en by wie is God? Praat Jesus die waarheid? Is Hy die Woord, wat die Vader kom bekend maak? (Joh 1:1, 18; Kyk Barrett 1978:169-170; Brown 1966:36; Carson 1991; Köstenberger 2004:48-49) $?^{12}$

\section{SLOT}

Dit blyk duidelik dat daar verskillende aksielyne in Johannes is wat verskillende tipes geweld verteenwoordig en word uiteindelik vervleg met die aksielyn van moord tot ' $n$ koherente geweldsprofiel. Die geweldsprofiel word teen die dekor van 'n dualistiese wêreldbeeld ontwikkel en uitgebou. In Johannes se denke is daar twee families elk met hulle eie pater familias en begronding vir hulle bestaan en hulle optrede (vgl Joh 16:2; 1:12; 8:44; kyk Van Tilborg [1993:34-53] vir 'n goeie bespreking van geboorte in die antieke Mediterreense konteks). Die kinders van die duiwel (Joh 8:44) word gekenmerk deur duisternis, sonde, leuens, haat, moord, blindheid, ensovoorts. Dit is dan juis hulle geestelike blindheid wat maak dat hulle nie geestelik kan sien nie (Joh 9:40-41; 12:40-41) en dat hulle aktief deelneem aan die vilifikasie van Jesus en sy dissipels (Joh 10:19). Die geweldsprofiel van die kant van die opponente van Jesus sluit nie alleen fisieke geweld in nie, maar veral ook sosiaal-religieuse geweld. Beide deur vilifikasie en deur aktiewe uitbanning uit die sinagoge (Joh 9:34; $\xi^{\prime} \xi \hat{\xi} \beta \propto \lambda \circ v$ ) is die navolgers van Jesus sosiaal geïntimideer. Die vilifikasie en aksielyne kulmineer uiteindelik in die moord van Jesus. Hiervolgens word dit duidelik dat Johannes se Evangelie van liefde inderdaad ook ' $n$ verhaal van geweld en vilifikasie is.

Binne die tipiese Johannese ironie lei die kruisgebeure egter ook tot die uitstorting van die Heilige Gees (Joh 20:22) en die moontlikheid tot herskepping van verlore lewensmoontlikhede. Anders gestel kan daar

\footnotetext{
${ }^{12}$ Ander minder prominente vorms van geweld tussen groepe in die Evangelie is eerstens geweld tussen Jode en Samaritane tot so 'n mate dat hul geen sosiale kontak het nie (Joh 4:9). Jesus se opponente beledig Hom deur Hom 'n Samaritaan te noem (Joh 8:48).

Tweedens is daar geweld tussen Jode en die Romeinse owerheid, soos blyk uit die gesprek in die Joodse Raad (Joh 11:46-50). Die Jode bely tydens die verhoor hulle onderdanigheid aan die keiser (Joh 19:15). Die laasgenoemde twee sydelingse opmerkings plaas die narratief binne die politieke spanningsveld van imperiale oorheersing. Dit word nie verder uitgewerk in die Evangelie nie. Daar is wel die opmerking dat Jesus in opdrag van die Romeinse verteenwoordiger gekruisig word. Derdens is daar geweld teen vroue. 'n Sydelingse opmerking deur die Samaritaanse vrou dat sy ' $\mathrm{n}$ vrou is wat nie verwag dat' $\mathrm{n}$ man met haar sal praat nie, dui op die kulturele gebruike van destyds wat onderskeid tussen die posisies van man en vrou gemaak het. In huidige kontekste word die onderskeid as geweldadig deur sommige beleef, maar in hierdie Evangelie word die saak nie bespreek of in fokus gebring nie.
} 


\section{Geweld in 'n evangelie van liefde}

geargumenteer word dat die krisis, geweld en konflik situasie in Johannes uiteindelik tot die ontsluiting van lewe lei. In die konteks van geweld, vilifikasie, vernietiging en gebrokenheid word die moontlikheid tot herskepping en restourasie gebore. Op hierdie wyse gaan die woorde van Johannes 1:5 in

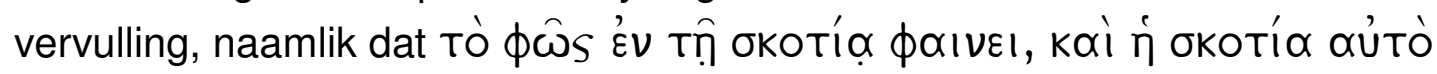

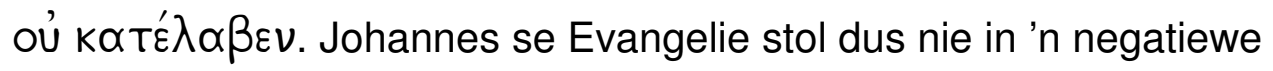
geweldsprofiel nie. In die konteks van geweld is daar in Johannes se teologie steeds vir die gelowige hoop.

\section{Literatuurverwysings}

Ashton, J 1994. Studying John: Approaches to the Fourth Gospel. Oxford: Clarendon.

Barrett, C K 1978. The Gospel according to St John. $2^{\text {nd }}$ ed. Philadelphia, PA: Westminster.

Bennema, C 2002. The power of saving wisdom: An investigation of spirit and wisdom in relation to the soteriology of the Fourth Gospel. Tübingen: Mohr Siebeck.

Bieringer R D (ed) 2001. Anti-Judaism and the Fourth Gospel. Louisville, KY: Westminster.

Bietenhart, H 1986. s v Demon, air, cast out in Brown C (ed), NIDNT. Grand Rapids, MI: Zondervan. (electronic edition.)

Brown, R E 1970. The Gospel according to John, Vol 2: Chaps 13-21. New York: Doubleday.

Brown, C (ed) 1986. New international dictionary of the New Testament. Grand Rapids, MI: Zondervan. (electronic edition.)

Carson, D A 1991. The Gospel according to John. Grand Rapids, MI: Eerdmans.

Coloe, M L 2001. God dwells with us: Temple symbolism in the Fourth Gospel. Collegeville, MN: Liturgical.

Culpepper, R A 1975. The Johannine school. Missoula, MT: Scholars Press. (SBLDS 26.)

Culpepper, R A 1981. The pivot of John's Gospel. NTS 27, 1-31.

Culpepper, R A 1983. Anatomy of the Fourth Gospel: A study in literary design. Philidelphia, PA: Fortress.

Culpepper, R A 1993. John 5:1-18: A sample of narrative critical commentary, in Stibbe, M W G (ed), The Gospel of John as literature: An anthology of twentieth-century perspectives, 193-207. Leiden: Brill.

Culpepper, R A 1995. The plot of John's story of Jesus. Interpr 49, 347-358.

Cullmann, O 1975. Der johanneische Kreis: Zum Ursprung des Johannesevangeliums. Tübingen: Mohr.

De Beer, C S 2007. Filosofiese besinning oor geweld: Uitdagings aan informatiseringstrategieë. Tydskrif vir Geesteswetenskappe 47, 3-27.

De Boer, M C 2001. The depiction of "the Jews" in John's Gospel: Matters of behaviour and identity, in Bieringer, R D (ed), Anti-Judaism and the Fourth Gospel, 141-157. Louisville, KY: Westminster John Knox. 
Desjardins, M 1997. Peace, violence and the New Testament. Sheffield: Sheffield Academic Press.

De Jonge, H J 2001. "The Jews" in the Gospel of John, in Bieringer, R D (ed), AntiJudaism and the Fourth Gospel, 121-140. Louisville, KY: Westminster John Knox.

Du Toit, A B 1994. Vilification as pragmatic device in early Christian epistolography, Biblica 75, 403-412.

Girard, R 1977. Violence and the sacred. Baltimore, MD: Johns Hopkins University Press.

Girard, R 1986. The scapegoat. Baltimore, MD: Johns Hopkins University Press.

Haenchen, E 1980. Das Johannesevangelium. Tübingen: Mohr Siebeck.

Haenchen, E 1984a. John (1). Philadelphia, PA: Fortress Press. (Hermeneia - A critical and historical commentary on the Bible.)

Haenchen, E 1984b. John (2). Philadelphia, PA: Fortress Press. (Hermeneia - A critical and historical commentary on the Bible.)

Hays, R 1996. Moral vision of the New Testament. San Francisco, CA: HarperCollins.

Johnson, L T 1989. The New Testament's anti-Jewish slander and the conventions of ancient polemic. JBL 108, 419-441.

Joubert, S, Van der Watt, J G \& Malina, B 1996. A time travel to the world of Jesus. Pretoria: NGKB.

Kok, J 2008. Siekte en gebrokenheid teenoor genesing en restourasie in Johannes. PhD-proefskrif, Universiteit van Pretoria.

Köstenberger, A J 2004. John. Grand Rapids, MI: Baker Academic. (Baker exegetical commentary on the New Testament.)

Kümmel, W G 1976. Theology of the New Testament. Study edition. London: SCM.

Lausberg, H 1960. Handbuch der literarischen Rhetorik. München: Hueber.

Lieu, J M 2001. Anti-Judaism and the Fourth Gospel: Explanation and hermeneutics in Bieringer, R D (ed), Anti-Judaism and the Fourth Gospel, 101-120. Louisville, KY: Westminster John Knox.

Malina, B J \& Rohrbauch, R L 1998. Social-science commentary on the Gospel of John. Minneapolis, MN: Fortress.

Malina, B J \& Neyrey, J H 1991. Conflict in Luke-Acts: Labeling and deviance theory, in Neyrey, J H (ed), The social world of Luke-Acts: Models for interpretation. Peabody, MA: Hendrikson.

Martyn, J L 2003. History and theology in the Fourth Gospel. 3rd ed. Louisville, KY: Westminster John Knox.

Metzner, R 2000. Das Verständnis der Sünde im Johannesevangelium. Tübingen: Mohr Siebeck.

Morris, L 1995. The Gospel according to John, rev ed. Grand Rapids, MI: Eerdmans.

Motyer, S 1997. Your father the devil?: A new approach to John and "the Jews". Carlisl: Paternoster.

Niebuhr, H R 1951. Christ and culture. New York: Charles Scribner's Sons.

Petersen, N R 1993. The Gospel of John and the sociology of light. Valley Forge, PA: Trinity.

Reinhartz, A 2001. Befriending the beloved disciple: A Jewish reading of the Gospel of John. New York: Continuum.

Ridderbos, H 1997. The Gospel according to John. Grand Rapids, MI: Eerdmans. 


\section{Geweld in 'n evangelie van liefde}

Schattenmann, J 1986. Ecstacy, astonishment, distraction, horror, madness in Brown, C (ed), NIDNT. Grand Rapids, MI: Zondervan. (electronic version.)

Schnackenburg, R 1971. Das Johannesevangelium. Freiburg: Herder. (HThK 4.)

Schnackenburg, R 1980. The Gospel according to St John, Vol II: Commentary on chapters 5-12. London: Burns \& Oates.

Schnackenburg, R 1982. The Gospel according to St John, Vol III: Commentary on chapters 13-21. London: Burns \& Oates.

Schnackenburg, R 1990. The Gospel according to St John, Vol I: Introduction and commentary on chapters 1-4. London: Burns \& Oates.

Stibbe, M W G 1993. John. Sheffield: Sheffield Academic Press.

Thyen, H 2005. Das Johannesevangelium. Tübingen: Mohr Siebeck.

Van der Watt, J G 2001. Fisiese en aardse families in die Evangelie volgens Johannes. Verbum et Ecclesia 22, 158-177.

Van der Watt, J G \& Joubert, S J 1996. Hoe is Jesus gekruisig? HTS 52, 633-652.

Van der Watt, J G 2003. The cross/resurrection-events in the Gospel of John with special emphasis on the confession of Thomas (20:28). Neotest 37, 127-145.

Van der Watt J G (ed) 2005. Salvation in the New Testament. Leiden: Brill.

Van der Watt J G 2006. Ethics and ethos in the gospel according to John. ZNW 97, 147-176.

Van der Watt, J G 2007. Introduction to John's Gospel and Letters. Edinburgh: T\&T Clark.

Van Tilborg, S 1993. Reading John in Ephesus. Leiden: Brill.

Witherington, B 1995. John's wisdom: A commentary on the Fourth Gospel. Louisville, KY: Westminster John Knox. 